\title{
SISTEM PENDIDIKAN PESANTREN DAN TANTANGAN MODERNITAS
}

\author{
Gatot Krisdiyanto $^{1}$, Muflikha $^{2}$, Elly Elvina Sahara ${ }^{3}$, Choirul Mahfud ${ }^{4}$ \\ ${ }^{1}$ Universitas Muhammadiyah Sidoarjo \\ ${ }^{2}$ Institut Teknologi Sepuluh November (ITS) Surabaya \\ email: choirulmahfud@gmail.com
}

\begin{abstract}
The exclamation of "Ayo Mondok" (Let's study in Islamic boarding school) is part of the pesantren (Islamic boarding schools) response to modernity. In this modern era, there are still many Muslim societies in Indonesia that make pesantren a reference for formal and informal educational institutions. Indeed, initially the pesantren was only traditional and only aimed to explore the religion knowledge. However, along with the modernization of the times, Islamic boarding schools have not only become institutions to explore religious knowledge but also general science. This article explains the bistory and development of pesantren, and how the system of pesantren education answers the challenges of modernity. To get the desired results, the research library was chosen by researchers as the research method in this study. The results of this study reveal that Islamic boarding schools are a gathering place for santri (students) to get religious knowledge from a cleric. The beginning of the pesantren was only a simple hut which was built as a makeshift with the aim of getting closer to the "kyai" or the teacher intended for the purposes of studying religion. While the system of pesantren education is still using the book of "salaf" or more familiarly called "kitab kuning".
\end{abstract}

Keywords: Islamic Boarding School, Modernity and Islamic Education

\begin{abstract}
Abstrak: Gerakan Ayo Mondok merupkan bagian dari respon pesantren menghadapi modernitas. Di era modern seperti ini, masyarakat Muslim di Indonesia masih banyak yang menjadikan pesantren sebagai rujukan lembaga pendidikan formal maupun informal. Memang pada awalnya pesantren hanya bersifat tradisional dan hanya bertujuan untuk mendalami ilmu agama saja. Akan tetapi seiring dengan modernisasi zaman, pesantren tidak hanya menjadi lembaga untuk mendalami ilmu agama saja tetapi juga ilmu umum. Tulisan ini menjelaskan tentang sejarah dan perkembangan pesantren, dan bagaimana sistem pendidikan pesantren menjawab tantangan modernitas. Untuk mendapatkan hasil yang diinginkan, maka library research dipilih oleh peneliti sebagai metode penelitian dalam studi ini. Hasil dari kajian ini mengungkapkan bahwa pesantren merupakan tempat berkumpulnya para santri untuk mendapatkan ilmu agama dari seorang kyai. Awal mula pesantren hanya berupa pondok sederhana yang dibangun seadanya dengan tujuan untuk mendekatkan diri kepada kyai atau guru yang dituju untuk keperluan menimba ilmu agama. Sedangkan sistem pendidikan pesantren sampai sekarang masih tetap menggunakan kitab salaf atau lebih familiar disebut kitab kuning.
\end{abstract}

Kata Kunci: Pesantren, Modernitas dan Pendidikan Islam 


\section{PENDAHULUAN}

Keberadaan pondok pesantren bukanlah suatu hal yang baru. Citra pondok pesantren juga sudah lama dikenal baik. Terbukti dari anggapan bahwa pesantren mampu membentuk pribadi yang berakhlakul karimah dan menghasilkan banyak kader ulama dan juga da’i. Namun begitu, semua masyarakat muslim di Indonesia masih meyakini bahwa pesantren mempunyai peran penting sebagai institusi penyiaran ajaran agama Islam di Indonesia. Transformasi pesantren juga teruji dari zaman ke zaman. Pendidikan pesantren merupakan pendidikan yang paling tua di Indonesia. Sampai sekarang, pendidikan pesantren ini juga masih tetap survive diantara pendidikan luar pesantren yang semakin modern. Meskipun juga ada pesantren yang dulunya mengalami kejayaan dan eksis pada masanya, sekarang mulai surut atau mengalami kemunduran. Hal itu salah satunya dikarenakan sistem pengkaderan yang tidak disiapkan, sehingga tidak ada generasi penerus yang kompeten dalam pesantren itu dan sebagai dampaknya, maka pesantren tersebut mengalami kesurutan.

Perlu diketahui bahwa keberlangsungan sebuah pesantren sangat bergantung pada daya tarik tokoh sentralnya (kyai) yang memimpin, penerus atau pewarisnya. Apabila pewaris menguasai banyak pengetahuan keagamaan, kewibawaan, keterampilan mengajar, dan hal lainnya yang diperlukan, maka bisa jadi pesantren tersebut akan mampu bertahan. Pesantren yang dengan serius mengkader generasinya sehingga pesantren tersebut bisa tetap eksis di tengah semakin kuatnya arus perubahan zaman. Pesantren tersebut merasa tertantang untuk memberi jawaban atas problematika pendidikan di masyarakat. Tentunya, pengkaderan untuk regenerasi kyai bukanlah satu-satunya cara supaya pesantren mampu tetap eksis, akan tetapi ada banyak hal yang harus mengalami pembaharuan dalam pesantren tersebut, seperti tentang kurikulumnya, sistem pendidikannya, dan juga masih banyak pembaharuan-pembaharuan yang lain.

Seiring dengan berjalannya waktu, pondok pesantren memang harus ada pembaharuan sesuai dengan tuntutan zaman. Masyarakat semakin mendapat kesempatan luas untuk berhubungan dengan dunia luar guna mendapatkan ilmu pengetahuan yang sebanyakbanyaknya apalagi setelah masa kemerdekaan. Pesantren juga melakukan hal yang sama yaitu melakukan kontak dengan dunia ilmu pengetahuan luar. Dengan begitu maka akan semakin banyak wawasan yang didapat agar pesantren bisa semakin maju dan berkembang. Meski tetap melaksanakan sistem pengajaran yang lama yaitu sorogan dan wetonan, pesantren mulai banyak mendirikan atau menyelenggarakan pendidikan formal seperti madrasah. 
Pada dasarnya penyelenggaraan sistem pendidikan dan pengajaran di pesantren digolongkan menjadi 3 macam yaitu yang pertama dengan cara non-klasikal (sistem bandungan dan sorogan) dimana seorang kyai mengajar berdasarkan kitab yang ditulis dalam bahasa Arab, dan kemudian para santrinya tinggal di pondok pesantren untuk belajar pada kyai tersebut. Yang kedua, dengan sistem weton, dimana santri datang berduyun-duyun pada waktu tertentu. Sebenarnya sistem weton ini sama dengan sistem yang pertama, akan tetapi bedanya adalah para santrinya tidak disediakan pondokan melainkan tinggal tersebar di seluruh penjuru desa sekeliling pesantren tersebut. Yang ketiga yaitu sistem pondok pesantren yang menggabungkan sistem bandungan, sorogan, dan juga wetonan. Pada sistem ini, pesantren juga menyelenggarakan pendidikan formal dalam bentuk madrasah bahkan sekolah umum berbagai tingkatan dan kejuruan sesuai kebutuhan masyarakat.

Didirikannya pondok pesantren pada awalnya hanya lebih mengedepankan pada ilmu pengetahuan agama saja, tetapi selanjutnya seiring dengan kebutuhan masyarakat dan semakin berkembangnya pendidikan, maka pondok pesantren sekarang ini tidak hanya berorientasi pada seputar pengetahuan ilmu agama saja (tafaqquhu fiddin) melainkan menjadi lebih meluas pada peningkatan kualitas sumber daya santri supaya mampu menghadapi kehidupan sesuai dengan tantangan zaman. Pesatnya perkembangan ilmu pengetahuan yang dimulai pada masa kerajaan bani umayyah membuat masyarakat Islam tidak hanya menuntut ilmu di masjid melainkan di lembaga-lembaga yang lain misalnya kutab yang di Indonesia lebih dikenal dengan sebutan "pondok pesantren”. Karakteristik pondok pesantren yaitu adanya kyai, santri, masjid, dan pondok.

\section{PEMBAHASAN}

Pesantren mempunyai arti tempat para santri (Zamakhsyari, 1982:18). Tempat dimana para santri belajar menuntut ilmu, terutama ilmu agama. Pesantren tersebut dibangun karena keinginan masyarakat akan adanya lembaga pendidikan lanjutan. Umumnya pondok pesantren mulai muncul dan berkembang pada daerah pedesaan disebabkan tuntutan masyarakat sekitar yang berkeinginan akan adanya pondok pesantren. Masyarakat yang memilih pondok pesantren sebagai lembaga pendidikan untuk anaknya sebagian besar didasari oleh rasa percaya akan pembinaan atau pendidikan yang dilakukan oleh pondok pesantren tersebut supaya anaknya dapat belajar ilmu agama yang lebih dalam.

Kebanyakan, suatu pesantren berawal dari pengakuan masyarakat akan keilmuwan dari seorang kyai atau guru. Karena mempunyai keinginan untuk belajar lebih dalam kepada kyai 
atau guru tersebut, banyak masyarakat datang kepadanya untuk menimba ilmu. Dan mereka membangun tempat tinggal seadanya di dekat rumah sang kyai yang dituju. Semakin tinggi tingkat keilmuwan seorang kyai atau guru, maka secara tidak langsung akan semakin banyak murid yang datang kepadanya. Menurut Poerwadarminta, pesantren merupakan asrama dan tempat murid belajar mengaji dan ilmu agama. Kata lain dari pesantren yaitu pondok yang juga mempunyai arti rumah yang sementara seperti yang didirikan di ladang, hutan, dan yang lainnya (Poerwadarminta, 1982: 764). Tujuannya untuk mendekatkan diri kepada kyai atau guru yang dituju untuk menuntut atau menimba ilmu. Sedangkan menurut Soegarda Purbakawarja, kata pesantren berasal dari santri yang memiliki arti orang yang mempelajari agama Islam, maka bisa dimaknai pondok pesantren ialah tempat banyak orang berkumpul untuk mempelajari agama Islam (Purbakawatja, 1976).

Lebih jelas lagi, Imam Zarkasyi mengartikan bahwa pesantren yaitu sebuah lembaga pendidikan Islam dengan sistem asrama atau pondok dimana kyai merupakan sosok sentralnya, masjid merupakan sentral kegiatan yang menjiwainya, dan pengajaran ajaran Islam dibawah bimbingan kyai yang diikuti santri merupakan kegiatan utamanya (Wirosukarto, 1996: 56). Maka bisa disimpulkan bahwa terdapat 4 unsur yang ada dalam pesantren yaitu: Kyai, masjid, ajaran Islam, dan santri. Juga, pesantren bisa diartikan sebagai ekosistem suatu tempat dimana para penghuninya banyak belajar tentang kehidupan dan berinteraksi satu sama lainnya dalam berbagai segi kehidupan dan aspeknya (Umiarso, 2011: 15-88). Hal itu dimaksudkan bahwa di dalam pesantren para santri belajar tentang bagaimana menjalani kehidupan Islami sesuai dengan syariat-syariat yang diajarkan dalam agama Islam. Tentunya hal itu sangat berguna dalam kehidupan selanjutnya ketika para santri tersebut sudah tidak lagi berada di dalam pesantren.

Maka dari itu diharapkan setelah para santri tersebut tidak lagi berada di pesantren, para santri bisa mengamalkan ajaran-ajaran ataupun hal-hal positif lainnya yang mereka dapat dari pesantren yang merupakan tempat mereka belajar kehidupan. Hal itu sesuai dengan tujuan pesantren yaitu yang meliputi tujuan umum dan tujuan khusus. Adapun tujuan umum pondok pesantren membimbing santrinya menjadi generasi berkepribadian Islam yang dengan ilmu agamanya mereka sanggup menjadi mubaligh Islam di masyarakat Islam melalui ilmu dan amalnya. Sedangkan tujuan khususnya yaitu menyiapkan para santri menjadi orang alim dalam ilmu agama yang mereka dapatkan dari para kyai saat di pondok pesantren serta mampu mengamalkannya dalam masyarakat. 


\section{Sejarah Perkembangan Pesantren}

Sejarah pertumbuhan masyarakat muslim di Indonesia sangat erat hubungannya dengan sejarah pondok pesantren. Hal ini bisa dibuktikan dari zaman kerajaan Islam yang pertama di Sumatera khususnya di Aceh pada awal abad tahun hijriyah pertama. Setelah itu pada kurun waktu walisongo sampai awal abad dua puluh banyak para wali dan ulama membuat desa baru yang kelak menjadi pesantren (Saridjo, 1982). Pada waktu itu, pesantren hanya dibuat secara sederhana yang berupa pondok-pondok atau bangunan yang hanya terdiri dari ruang-ruang utama saja yang tujuannya hanya untuk tempat tinggal sementara selama para santri ingin menimba ilmu dari seorang kyai. Para santri biasanya mendirikan pondok tersebut disekitar kediaman rumah kyai atau guru yang mereka anggap tinggi tingkat keilmuannya. Pada masa perjuangan mengusir penjajah di Indonesia, pondok pesantren turut mengambil peran dalam sektor pendidikan yang bertujuan untuk membuat masyarakat Indonesia maju dan cerdas dalam hal pemikiran (Muammar, 2016). Hal tersebut ditunjukkan dengan adanya upaya di dalam pesantren tersebut pendidikan-pendidikan untuk rakyat jelata supaya mereka sedikit banyak mempunyai wawasan ataupun hanya sekedar baca tulis. Juga, selain ikut andil dalam bidang pendidikan, pesantren juga ikut andil dalam usaha mengusir penjajahan di Indonesia pada waktu itu. Banyak gerakan-gerakan dalam pesantren yang dilakukan dalam usaha memperoleh kemerdekaan, seperti yang dilakukan oleh para kyai di pondok pesantren tebu ireng yang seringkali menyusun rencana dan strategi dalam usaha mengusir penjajah di Indonesia. Beliau, para kyai ini menyusun strategi dalam pesantren dan kemudian melakukan gerakan-gerakan untuk mengusir para penjajah dari Indonesia.

Seiring dengan berkembangnya zaman, pesantren kini mengalami modernisasi. Pesantren yang dulu hanya sekadar pondok atau tempat tinggal yang digunakan supaya bisa tinggal berdekatan dengan seorang kyai atu guru guna menimba ilmu kepadanya, sekarang berubah menjadi bisa dikatakan sebuah lembaga pendidikan dimana seseorang bisa mendapatkan ilmu umum maupun agama. Dengan dinamikanya, pesantren dianggap sebagai lembaga pendidikan Islam yang menjadi sentral dari perubahan-perubahan masyarakat melalui aktivitas-aktivitas dakwah Islam seperti yang tercermin dari beberapa pengaruh pesantren terhadap perubahan dan pengembangan pribadi sampai pada politik diantara pengasuh pondok serta pemerintah. Ini terjadi tidak hanya pada pesantren sekarang ini, akan tetapi itu sudah terjadi sudah sejak masa penjajahan Belanda dahulu.

Dalam bidang pendidikan, pesantren memang lebih dikenal sebagai lembaga pendidikan Islam yang di dalamnya terdapat proses belajar dan mengajar ilmu agama Islam dan juga sebagai lembaga penyebaran agama Islam. Dalam proses belajar mengajar yang ada 
di dalam pesantren, Islam merupakan agama yang tidak hanya mengajarkan amalan-amalan peribadatan saja, apalagi hanya mengajarkan hubungan antara manusia dengan sang penciptanya saja, akan tetapi Islam juga mengajarkan perilaku dan hubungan yang baik antara manusia dengan sesamanya di dunia. Bisa juga dikatakan, hablu minna naas dan bablu minna Allah. Karena dalam menjalani kehidupan yang nyata nantinya. Karena jika kita hanya menjalin hubungan yang baik dengan Tuhan saja, maka kita akan menjadi individu yang tidak peka dalam artian tidak punya rasa toleransi dengan sesama. Sebaliknya jika kita hanya menjalin hubungan yang baik hanya dengan sesama saja maka kita akan menjadi pribadi yang tidak seimbang.

\section{Sistem Pendidikan Pesantren dan Tantangan Modernitas}

Ada salah satu ciri tradisi yang selalu dipertahankan dalam pesantren yaitu pengajian kitab salaf atau yang lebih familiar disebut kitab kuning. Para sarjana Islam pada abad pertengahan membuat kitab itu (Kitab salaf) yang sampai sekarang pun pesantren juga masih rutin melakukan pengajian dengan kitab tersebut (kitab salaf atau kitab kuning). Kitab salaf atau kitab kuning tersebut merupakan karya intelektual muslim yang sangat berharga dan tidak ternilai harganya. Dalam kitab kuning tersebut, ada dua unsur yaitu matan dan sharah. Matan merupakan bagian inti yang dibahas pada bagian syarah. Pada zaman sekarang ini, keberadaan kitab salaf menjadi saling terkait dengan kebeadaan sang kyainya. Kitab salaf adalah kodifikasi nilai yang dianut oleh para santri di pesantren, sedangkan kyai adalah cermin dari semua yang diteladani (Mas'udi, 1985: 56). Maksudnya ialah kitab salaf adalah kitab yang berisi ilmi-ilmu mulai dari ilmu tentang aqidah, ilmu tafsir, tata bahasa arab, ilmu hadits, ilmu fiqih, bahkan ilmu sastra yang merupakan materi yang diajarkan pesantren kepada santrinya dan sosok kyai merupakan sosok yang menguasai dalam penerapan ilmu-ilmu tadi.

Sebelum membahas tentang sistem pendidikan pesantren, ada baiknya mengenal lebih dulu sekilas tentang kitab kuning, kitab yang dianggap sangat penting di kalangan pesantren. Kitab ini tidak lebih besar dari ukuran kertas kwarto. Kitab ini disebut kitab kuning karena halaman kertasnya yang berwarna kuning,tidak berwarna putih seperti warna kertas pada umumnya. Meskipun ada versi terjemahannya, kitab ini aslinya menggunakan bahasa arab tanpa harokat atau yang biasa disebut arab gudul (pegon). Kitab ini biasanya sangat tebal, akan tetapi biasanya didesain per bab yang isinya hanya beberapa lembar saja. Sehingga terlihat tipis. Hal ini bertujuan supaya santri bisa lebih ringan menbawanya karena biasanya santri hanya membawa bagian kitab kuning yang akan dipelajarinya saja. 
Namun demikian, tiap pesantren mengajarkan kitab yang berbeda. Karena dalam kitab kuning ada banyak jurusan ilmu yang berbeda-beda maka banyak kyai terkenal dengan spesialisasi kitab tertentu karena kyai tersebut menguasai pada bidang tersebut, seperti halnya seorang dokter anak yang spesialisasinya hanya pada penyakit anak saja. Demikian juga kyai, meskipun pada dasarnya mereka juga mengerti semua bidang atau jurusan keilmuan agama, akan tetapi mereka hanya menguasai atau spesialis dibidang tertentu saja

Sistem pendidikan yang ada di dalam pesantren mempunyai karakter yang mandiri. $\mathrm{Hal}$ itu bisa kita lihat dari pengajaran sorogan. Pengajaran sorogan di sini maksudnya adalah seorang kyai mengajar para santrinya secara bergiliran dari santri satu ke santri lainnya. Saat tiba gilirannya, santri mengulangi serta mengartikan kata yang sama persis dengan yang diucapkan kyai atau guru itu kepadanya. Metode penerjemahan ini dibuat supaya mereka bisa dengan mudah mengerti dan memahami baik dari segi arti ataupun fungsi kata dalam rangkaian kalimat dalam bahasa Arab.

Dalam sistem itu, para santri harus melakukannya secara berulang-ulang dan hanya boleh menerima tambahan pelajaran apabila sudah mendalami atau menguasai pelajaran sebelumnya. Sorogan bisa diartikan sebagai sistem yang paling sulit dari keseluruhan sistem pengajaran yang ada di pesantren, hal ini disebabkan dalam sorogan para santri dituntut untuk sabar, rajin, taat, dan disiplin. Selain sorogan dalam pesantren juga sangat familiar dengan yang namanya pengajian weton dimana sang kyai bersila di lantai masjid atau di teras rumahnya membaca atau menjelaskan tentang hal-hal yang bersifat keagamaan dan para santrinya mengerumuninya sambil mendengarkan dan mencatat apa yang disampaikan oleh kyai tersebut. Dalam pengajian sorogan, metode yang digunakan adalah masih dilanjutkan dengan cara memberi kuasa kepada para ustadz untuk melaksanakannya di bilik atau kamar mereka masing-masing. Dan lama kelamaan maka pengajian weton digantikan ke pengganti kyai (badal), jadi hanya pengajian weton dengan teks utama yang diberikan oleh sang kyai. Seiring dengan perkembangannya, sistem klasikal digunakan dalam proses pembelajaran sebagai pembaharuan dari model sorogan serta model weton (Wahjoetomo, 1987: 82; Matsuhu, 1994: 61).

Dalam tulisannya, Abdorrahman menjelaskan 8 (delapan) pola umum tentang pendidikan Islam di pesantren yaitu sebagai berikut: Hubungan yang dekat diantara kyai dan santri; Pola hidup sederhana (zuhud); Tradisi ketundukan atau kepatuhan seorang santri kepada kyai; Sifat mandiri dari seprang santri; Berkembangnya budaya tolong menolong dan suasana persaudaraan antar sesama santri; Sifat disiplin yang tinggi; Rela hidup menderita demi tercapainya tujuan; Kehidupan dengan tingkat religuitas yang tinggi (Mas'ud, 2002: 14). 
Pesantren, meskipun terlihat menomerduakan urusan duniawi dan lebih mengutamakan hubungan dengan Allah sang penguasa alam, sekarang sangat diminati keberadaannya. Masyarakat justru menyambut baik adanya pesantren untuk perbaikan akhlak dan moral generasi. Singkat kata, salah satu tujuan memilih pesantren sebagai lembaga untuk menimba ilmu adalah supaya bisa berjiwa Islami, berakhlak terpuji, selain sisi akademis yang juga menjadi tujuannya.

Dengan memiliki karakteristik yang khas, pesantren menjadi pusat pendidikan Islam yang survive keberadaannya dalam melestarikan tradisi-tradisi pesantren ditengah arus perubahan zaman yang semakin modern ini. Karakter khusus di pondok pesantren yaitu isi kurikulum yang fokus pada ilmu agama seperti hukum Islam, tafsir, hadits, tasawuf, retorika, tarikh,sistem yurisprudensi Islam, dan juga theologi Islam. Mengenai mekanisme kerja, pondok pesantren mempunyai keunikan dibanding dibanding dengan lembaga pendidikan pada umumnya. Keunikan yang pertama yaitu masih memakai sistem tradisional dimana adanya kebebasan penuh dibanding dengan sekolah moderen sehingga terjadilah hubungan dua arah antara kyai dan santri. Keunikan yang kedua adalah sistem kehidupan di pondok pesantren sangat mengutamakan kesederhanaan, idealisme, persamaan, persaudaraan, dan keberanian hidup.

Sedangkan dalam hal penyaluran ilmu agama Islam, yang ditransfer oleh pesantren adalah fakta yang riil yang merupakan bentuk keseriusan lembaga pesantren dalam melestarikan dan menjaga kelangsungan Islam. Juga, ini dibuktikan dengan semakin banyaknya para intelektual muslim lahir dari pesantren. Peran yang seperti ini diharapkan mampu mencetak genarasi muda Islam yang mampu menghadapai perubahan zaman, dan menyesuaikan dengan lingkungan tempat tinggalnya, serta cakap dalam menghadapai permasalahan-permasalahan yang muncul di sekitar mereka adalah menjadi bahan pertimbangan prioritas dalam melakukan perbaikan dan pengembangan serta pembaharuan pendidikan pesantren (Abdullah, 2008: 1-19). Maka peran yang bisa dilakukan ialah bagaimana cara memberi fasilitas para santri supaya bisa menguasai ilmu pengetahuan yang mendasar dan selanjutnya bisa menjadi dasar keilmuwan yang lebih tinggi pada masa berikutnya (Abdullah, 2008 : 118). Azyumardi Azra mengatakan bahwa sistem pendidikan pesantren yang masih bersifat tradisionil adalah lembaga pendidikan Islam indigenius yang perlu kiranya ada pembaharuan (Priyanto, 2006: 20-37).

Dalam konteks ini, pesantren merupakan tempat para santri dimana para santri belajar menimba ilmu, terutama ilmu keagamaan. Pesantren tersebut dibangun karena keinginan masyarakat akan adanya lembaga pendidikan lanjutan. Kebanyakan, suatu pesantren bearawal 
dari pengakuan masyarakat akan keilmuwan dari seorang kyai atau guru. Maka dari itu, karena mempunyai keinginan untuk belajar lebih dalam kepada kyai atau guru tersebut, banyak masyarakat datang kepadanya untuk menimba ilmu. Dan kemudian mereka membangun tempat tinggal seadanya di sekitar tempat tinggal sang kyai atau guru tersebut.

Pada waktu itu pesantren hanya dibuat secara sederhana yang berupa pondok-pondok atau bangunan yang hanya terdiri dari ruang-ruang utama saja yang tujuannya hanya untuk tempat tinggal sementara selama para santri ingin menimba ilmu dari seorang kyai. Seiring dengan berkembangnya zaman, pesantren kini mengalami modernisasi. Pesantren yang dulu hanya sekedar pondok atau tempat tinggal yang digunakan supaya bisa tinggal berdekatan dengan seorang kyai atu guru guna menimba ilmu kepadanya, sekarang berubah menjadi bisa dikatakan sebuah lembaga pendidikan dimana seseorang bisa mendapatkan ilmu umum maupun agama disana.

Sistem pendidikan yang ada di pesantren mempunyai watak yang mandiri, hal itu bisa dilihat dari pengajaran sorogan. Pengajaran sorogan disini maksudnya adalah seorang kyai mengajar para santrinya secara bergiliran santri demi santri. Pada saat tiba gilirannya, santri mengulang serta mengartikan kata-kata sama persisnya seperti yang diucapkan kyai atau guru itu kepadanya. Demikian pula lama kelamaan maka pengajian weton dialihkan kepada pengganti kyai (badal) sehingga hanya teks-teks utama pada pengajian weton saja yang diberikan oleh sang kyai. Maka dari itu sistem pendidikan pesantren yang masih bersifat sangat tradisional yaitu lembaga pendidikan Islam indigenius juga perlu kiranya dilakukan pembaharuan. Implikasi idoelogi tajdid di pesantren terhadap penyelenggaraan pendidikan Islam di pesantren setidaknya dapat dilihat dari beberapa aspek, yaitu implikasi terhadap landasan filosofis, manajemen kelembagaan, pengembangan kurikulum dan pengaruh pondok pesantren terhadap faham keagamaan masyarakat lingkungan pesantren.

\section{PENUTUP}

Tantangan modernitas di pesantren bisa dipahami dari sistem manajemen pendidikannya. Manajemen kelembagaan pesantren selalu terkait erat kaitannya dengan perencanaan, pergorganisasian, pengarahan dan pengawasan. Bagaimana pesantren merencanakan, mengorganisir, mengarahkan, dan mengawasi kegiatan yang ada di lembaga pesantren. Baik kegiatan yang dilakukan oleh santri, guru dan kegiatan kelembagaan, serta bagaimana system rekrutken tenaga pendidik di pesantren tersebut. Pengembangan kurikulum pesantren, pesantren merupakan sebuah lembaga pendidikan Islam dengan ciri kas tersendiri, 
ciri khas tersebut merupakan refleksi dari ideologi yang dianut oleh kyai kemudian diimplementasikan dalam proses belajar mengajar. Adapun pengembangan kurikulum sangat erat kaitannya dengan tujuan, materi, strategi, media, proses belajar mengajar, dan evaluasi. Yang terakhir adalah lingkungan sekitar pesantren, pesantren atau lembaga pendidikan tidak hanya dinilai dari konsep keilmuan yang dikembangkan atau beberapa aspek yang tersebut di atas saja, akan tetapi pesantren atau lembaga tersebut berpengaruh terhadap pemahaman keagamaan masyarakat pesantren, atau sejauh mana pesantren dapat mewarnai masyarakat sekitar pesantren yang sangat dinamis di tengah kemajuan modernitas.

\section{REFERENSI}

Abdullah, Irwan dan Muhammad Zain \& Hasse J (Eds). (2008). Agama, Pendidikan Islam dan Tanggung Jawab Sosial Pesantren, Yogyakarta: Sekolah Pascasarjana UGM bekerja sama dengan Pustaka Pelajar.

Mahfud, Choirul. (2016). Politik Pendidikan Islam, Yogyakarta: Pustaka Pelajar.

(2018). Chinese Muslim Community Development in Contemporary Indonesia: Experiences of PITI in East Java, Studia Islamika 25 (3).

Mas'ud, Abdurahman, dkk. (2002). Dinamika Pesantren dan Madrasah, Yogyakarta: Pustaka Pelajar

Mas'udi, Masdar F. (1985). Mengenal Pemikiran Kitab Kuning, dalam Dawam Rahardjo (Ed.), Pergulatan Dunia Pesantren, Jakarta: P3M.

Matsuhu. (1994). Dinamika Sistem Pendidikan Pesantren, Jakarta: INIS.

Muammar, Arfan. (2016). Islam Puritan di Pesantren, Surabaya: Refka Media Pertama.

Malik A. Fadjar. (1999). Reorientasi Pendidikan Islam, Jakarta: Fajar Dunia.

Nata, Abudin. (2006). Modernisasi Pendidikan Islam di Indonesia, Jakarta: UIN Jakarta Press.

Naim, N. (2011). Teologi Kerukunan: Mencari Titik Temu dalam Keragaman. Teras.

Priyanto, Dwi. (2006). Inovasi Kurikulum Pesantren: Memproyeksikan Model Pendidikan Alternatif masa Depan, Ibda P3M STAIN Purwokerto, 4 (1).

Purbakawatja, Soegarda. (1976). Ensiklopedi Pendidikan, Jakarta: Gunung Agung.

Sujadi, Eko. (2017). Penerapan Pendidikan Karakter Cerdas Format Kelompok Untuk Meningkatkan Nilai Kejujuran Mahasiswa Bimbingan Konseling Islam (BKI) Institut Agama Islam Negeri (IAIN) Kerinci. Tarbawi : Jurnal Ilmu Pendidikan, 13(1): 97-108 
Sujadi, E., \& Wahab, M. (2018). Strategi Coping Korban Bullying. Tarbawi : Jurnal Ilmu Pendidikan, 13(2), 21-32.

Wahjoetomo. (1997). Perguruan Tinggi Pesantren, Jakarta: Gema Insani Press.

Wirosukarto, Amir Hamzah, dkk. (1996). KH.Imam Zarkasyi dari gontor merintis pesantren modern, Ponorogo: Gontor Press. 